\title{
Local expertise and global packages of aid: The transformative role of volunteerism and locally engaged expertise of aid during the 2006 July war in Lebanon
}

Lamia Moghnieh

\begin{abstract}
This case study addresses the role and impact of independent volunteering forms and initiatives during war by focusing on three examples from the July War in 2006, as experienced and narrated by several humanitarian volunteers and experts. This study argues that acts of volunteerism produce locally engaged forms of expertise that have the ability to challenge, direct, and transform global packages of aid into more locally informed and effective interventions. The personal and political transformations that volunteers experience, and the deep form of local expertise they acquire are important resources in communal responses to war and conflict. They reveal the importance of local forms of expertise in challenging and transforming universal humanitarian programs, policies and visions of how to intervene during war.
\end{abstract}

Keywords: Volunteerism; Local expertise; July war; Global aid.

To cite this paper: Lamia Moghnieh, "Local expertise and global packages of aid: The transformative role of volunteerism and locally engaged expertise of aid during the 2006 July war in Lebanon ", Civil Society Knowledge Center, Lebanon Support, July, 2015 . DOI: 10.28943/CSKC.001.30006. [ONLINE]:

https://civilsociety-centre.org/paper/local-expertise-and-global-packages-aid-transformative-rolevolunteerism-and-locally-engaged

This case study explores the relationship between volunteerism and the building of local expert knowledge during war in Lebanon. Drawing from three local experiences and initiatives thats emerged in response to the July war in 2006 , this case study explores the ways in which volunteerism produces locally informed and politically engaged experts that have the ability, resources and skills to effectively respond to war and crisis by contributing their local knowledge to relief and aid. This case study also addresses the difference between locally informed and engaged expertise and standardized-globalized humanitarian skills and packages of aid, universally adopted by humanitarian organizations during emergencies and wars.

This study relies on three case studies of local forms of volunteer aid that emerged out of the 2006 war to provide specific kinds of support and expertise for war-affected communities. These three examples are: 1) the intersubjective experience of volunteering in Samidoun during the war;12) the experience of the Reconstruction Unit team in postwar reconstruction and 3) the psychosocial knowledge base and tools formed during the July war. These examples highlight the importance of volunteering in responses to war and conflict as well as the role of locally emergent expertise in informing and challenging global humanitarian programs, concepts and procedures during war and in its aftermath. 
After addressing the methodology, the next section will describe the first case study on the meaning of volunteering during war, while the second and third sections will respectively document the architecture and psychosocial experiences of volunteering. The last section will analyze the themes emerging from these case studies and engage them with the work of global humanitarian interventions.

A roundatable discussion was held on the topic of the case study, both informing it and drawing its limitations. In the roundtable, some of the topics discussed revolved around the decline of the volunteer culture and local engagements in Lebanon, local experiences of support and community-building during the 2006 and presently, the role of volunteer-based organizations during war and postwar periods, the importance of building on local expertise through the use of local resources, manuals and skills in the current Syrian refugee crisis and the concept of international volunteerism. While this case study focused on grassroot forms of volunteerism that emerged in various forms under Samidoun during the war, and was itself shaped by professionalized and political schools of engagement, the study did not specifically research volunteer-based organizations and their role during past and current conflicts.

\section{Methodology}

The selection of the three case studies of local volunteering and expertise was based on their representation of important forms of local aid and expertise that influenced the work of global humanitarian organizations. The selection is therefore not representative of all forms of local experiences, initiatives and expertise that emerged in 2006. These examples serve to highlight the tension between local and global forms of expertise that this case study is addressing.

While the history of volunteering in Lebanon is rich with experiences, 2 several of which emerged out of volunteer-based organizations like the Lebanese Red Cross, Mouvement Social and others, this case study focuses more on organic forms of volunteering that emerged outside institutional structures in response to the July war. However, as some of the examples will show, volunteering was still informed by these prior institutional experiences and understandings of aid as a personal and political commitment.

The first example of volunteerism was based on in-depth interviews with several activists around their volunteer work during and after the July war. It also relied on in-depth interviews with first-time volunteers, volunteering at Ziko house relief center, and at Sanayeh center during the July war. $\underline{3}$ These interviews were necessary to capture the transformation that volunteers experienced on a personal level and in their relationship with each other at the centers. The second example was based on published literature documenting the experience of the Reconstruction Unit team, and interviews with some of its members. The third example is based on interviews conducted with mental health practitioners on the status of mental health services during the war, as well as with local psychosocial experts who volunteered during the July war.

\section{Volunteering during the war: inter-subjective transformation in times of war and violence}

This case study addresses the importance of individual volunteering during war and the inter-subjective, political and social transformation experienced by volunteers. 4 It follows the experience of individuals volunteering in Ziko house and Sanayeh relief centers during the July war, under the initiative of 
Samidoun. As argued before, Samidoun, if anything, presented a platform and network for a volunteerbased national solidarity and relief campaign that included different forms of groups, organizations and collectives, from university clubs, radical leftist groups, Palestinian groups and organizations, nongovernmental organizations (NGOs), socialists, political party organizations and human rights groups. $\underline{5}$

This platform also relied on and mobilized a baseline of independent individuals reaching out to volunteer during the war. $\underline{6}$ Many of the organizers and mobilizers of Samidoun, along with many volunteers, came from "Mouvement Social", a volunteer-based NGO with an extensive history of training youth in political and social organization.7 The organizers build on the social capital, skills and know-how they acquired at "Mouvement Social" to organize themselves, recruit, and form volunteers. In many cases, the volunteers were not simple executers and implementers of relief programs, but were involved in strategic planning for daily actions, political discussions and general meetings held during the war. $\underline{8}$

Volunteers came from different political, national and social backgrounds. 9 Some had previous experiences from the Israeli attacks in 1996, others were Palestinian refugees with a specific understanding of conflict and crisis. 10 Some lived in the suburbs of Beirut or had families in the South, areas that were mainly targeted by Israel during the war.11 Interviews clearly show that volunteers came from different backgrounds, in terms of social class, gender, sexual orientation and regional origin.12 This sometimes caused clashes and problems on a daily basis during the relief process.13 Out of these clashes, some volunteers changed their attitudes and behaviors as they learned to accept different opinions, lifestyles and beliefs, change their own gendered stereotypes, 14 and work with others with an opposing political or socio-moral worldview from their own.15

In-depth interviews with two volunteers, who both helped provide aid during war and were among those who stayed to participate in the postwar relief in the South, 16 revealed that they both experienced their act of volunteering as a transformative experience that informed and shaped their life, socio-political understandings, and involvement in future similar initiatives. One recurring theme in both interviews was the idea of "belonging", where both interviewees spoke of the feeling of finally belonging to a group of people who were perceived to be outside of, or at least seeking to challenge, sectarian and gendered structures in Lebanon.17 Relief became a personal and political act that engaged these volunteers to act in response to the war, turning them into active actors that possessed both consciousness and skills. In this vein, the study of Samidoun corroborates other research on activism/volunteerism that have shown how it constitutes a social and political "school" that may lead to other types and forms of engagement.18

Furthermore, volunteering during the war played a significant role in the type of employment both these interviewees ended up in, as well as their subsequent involvement in social projects and movements.19 While both remember this experience as transformative, their own ideals of what activism looks like was also faced with disillusionment and disappointment as a result of different clashes, fights in Samidoun on one hand, and the "corruption" and "mess" in the humanitarian aid field especially in the postwar reconstruction phase.20 Finally, interviewees spoke of the different relationships that were formed between volunteers who came from different backgrounds and the experience of working together through this difference. To summarize, Samidoun brought together 
various different professional activists and expert organizers. But it also enabled the creation of a space in which young and independent individuals were socialized into engaged volunteering, transforming them on an inter-subjective and political level into local actors, conscious and aware of the structural problems of the Lebanese context, and who acquired the capacity and resources to challenge them. Volunteering during the war became an experience for first-time volunteers that transformed them into locally involved and interested actors in the war period and beyond. This experience informed the way they understood the social, economic and political situation in Lebanon and pushed them toward a deep individual commitment to the community they were part of.

\section{The Reconstruction Unit team: influencing and challenging the process of postwar reconstruction}

After the ceasefire went into effect and families returned to their destroyed villages in 2006, the role of the Lebanese State became more directed towards coordinating postwar relief and assistance with international humanitarian organizations, leaving the reconstrution planning process to international organizations, companies and donor society states, like Qatar, Iran, Kuwait and others. 21 At the end of the war, a group of architects, planners and academics from the American University of Beirut and other independent professionals, formed The Reconstruction Unit (RU), $\underline{22}$ in order to volunteer their expertise and participate in the postwar reconstruction process in South Lebanon and the suburbs of Beirut. The unit was informed by the specific local expertise of its members, based on their insights into the politics of global projects of postwar reconstruction in Lebanon in prior experiences like the postwar reconstruction of Beirut in the 1990s.23 The Unit sought to "envision new ways of going about reconstruction that would avoid pitfalls of past practices",24 and influence the international reconstruction projects by claiming the need for more participatory approaches in the rebuilding of cities and villages, while sharing their knowledge and experience in urban planning and society.

While most local groups and organizations have focused on aid after the war, the Reconstruction Unit $(R U)$ focused on the challenges of the reconstruction of Lebanon's infrastructure, cities and villages destroyed during the war, aiming at linking the process of reconstruction to social and economic practices, 25 and raising critical debates on the politics of reconstruction and its effect on identity, society and space. The RU was composed of four groups working on sites deemed most vulnerable: Harat Hreik, Bent Jbeil, Aita al Chab and al-Qleileh and Saddiqine.26 "Lessons in postwar reconstruction: case studies from Lebanon in the aftermath of the July war" $\underline{27}$ documents the different experiences of the four groups in influencing the politics of reconstruction in general and challenging the decision-making process dominated by few political groups in the South and Beirut's suburbs like Hezbollah and Amal Movement. Some of the projects and initiatives undertook by the different groups were: launching an international ideas competition to influence the planning process; engaging in visits and discussions with public actors like municipality personnel, homeowners, the council of the south, Arab donor governments and states, brokers and local authorities; media pieces on the processes of reconstruction; holding public debates with reconstruction companies like Wa'd; conducting research and critical analysis on the urban reconstruction projects; and pushing for the preservation of old heritage town villages that were partly destroyed during the war, rather than their demolishing and complete rebuilding. $\underline{28}$

As mentioned above, RU team members knew what postwar reconstruction meant from their 
experience during the civil war and from the experience of other countries as well. 29 They had their eyes on the reconstruction process and they were aware of the importance of this process. They provided their expertise and called for local participation to influence the process of postwar reconstruction, so that it does not contribute to more physical destruction of the urban and rural fabric in south Lebanon and the suburbs of Beirut. Their vision of the postwar reconstruction went beyond monetary reimbursement, which seemed to be the main focus in the 2006 postwar reconstruction. 30 One emergent concern for this team at that time was the issue of heritage and the conservation of old buildings in South Lebanon, especially in Aita al Chaeb. While many of the houses and buildings were only partly demolished in the war, the plan was to demolish them further in order to rebuild new housing from scratch.31 Local volunteer experts called for meetings and citizen participation to challenge this style of reconstruction. This produced conflicts and clashes between them and homeowners, local contractors, political parties, municipalities and donor society funders involved, who came with a specific plan to demolish and rebuild entire villages without taking into consideration the importance of heritage and restoration as an alternative form of postwar reconstruction. 32

These clashes were somewhat the result of the emergent postwar political economy that was directly informed by urban reconstruction projects as conceived by international companies following the vision and demands of donor societies. For example, in Aita Al Chaeb, it was in the homeowners' own interest to destroy their houses, in order to sell the debris and get compensation to build a new ones.33 The volunteer experts, somewhat strangers to the village, tried to challenge and influence this established political economy of reconstruction. While only one house was restored in Aita al Chaeb, the volunteer experts recorded and mapped the old to-be-demolished houses of the village. 34 They also transmitted their experience in Aita Al Chaeb to Bent Jbeil, a neighboring village that also suffered destruction during the war but whose old city structure was still able to be restored, rather than demolished-then-rebuilt. 35 Bent Jbeil's case was more successful because there was a much clearer awareness of the importance of heritage there and more influential actors who were able to push efficiently for a restorative rather than a destructive plan of reconstruction.

To summarize, the experience of the Reconstruction Unit team is very diverse and rich and comprises multiple perspectives and lessons learned. From the short summary that this case study provides, this example seeks to show that local university and volunteer experts in architecture and urban planning were informed by and able to understand the importance of the physical and social processes of postwar reconstruction in Lebanon. They were able to, through volunteering their own local expertise, advance different visions and forms of reconstruction projects, like the restoration plan, that took into consideration the effect of reconstruction on social life and identity, $\underline{36}$ thereby challenging and influencing existing global projects of reconstruction.

\section{The Psychosocial Unit in Samidoun: informing and transforming universal programs of psychological aid}

In response to the July war, many teams, groups and units were loosely formed under Samidoun in order to address the mental health needs and demands of war-affected communities. They were composed of social workers, psychologists, students, theater majors, animators and independent volunteers, among other groups. 37 Interventions were invented, formed and transformed depending on the needs and demands imposed by the evolving war. 38 Some interventions first focused on the 
children, but there was soon a realization that working with displaced children without working with their parents or families was somewhat useless and ineffecient. The need for a comprehensive psychosocial and community-based mental health approach, especially during emergencies and war, seemed fundamental for alleviating the psychological distresses of displaced families.39 Volunteers used their theater and practitioner skills to perform these interventions in schools and tried to involve the whole family in the process.

Psychosocial interventions and programs, emergent from different groups volunteering under Samidoun, were implemented since the first days of the war, based on the volunteers' own skills and resources. $40 \mathrm{It}$ is also worth noting that there were discussions and debates on the appropriate ways to psychological intervention during armed conflicts and disasters, prior to the eruption of the 2006 war. The Arab Resource Collective (ARC), whose work focuses on producing and reinforcing local resources and skills in the Arab world, organized an Arab regional consultative workshop on mental health and psychological support during difficult circumstances.41 Experts came from Palestine and Iraq, countries that were thought to be most likely to suffer from future crises and conflicts. Experiences were shared on what was thought to be the most appropriate mental health resources that should be used during conflicts in the region.42 The July War broke out only a month after the workshop was held, which provided some kind of structure or vision on how mental health during war should be addressed and treated.

The volunteer-based psychosocial experiences acquired in the field were later transferred to meetings held during the war in the Ministry of Social Affairs with different mental health professionals, psychiatrists, psychologists and psychoanalysts. In these meetings, professional debates emerged on the proper resources and approaches to use in addressing the mental health of displaced families. The World Health Organization (WHO) had called local psychiatrists and psychologists and their institutions to mobilize and open psychiatric hospitals and mental health facilities to receive traumatized communities, and especially children. A heated debate emerged in these coordination meetings as some psychiatrists and psychologists following a more global understanding of mental health during wars were arguing for a more clinical form of intervention, through diagnosing displaced communities with Post-Traumatic Stress Disorder (PTSD) and treating them clinically with medications and psychotherapy. $\underline{43}$

On the other side of the debate, local experts and volunteers advanced a more community-based, locally informed and "holistic" mental health intervention that take into consideration the political and historical context in which war-affected communities were experiencing the war. This type of communitybased mental health was thought to be more efficient and relevant, rather than adopting universal forms of psychiatric and clinical diagnoses and university-level theories of psychotherapies in wars.44 At the heart of these debates was a critique of PTSD as a valid universal form of psychological suffering during wars and the importance of using and employing available and local mental health resources that take into consideration the historical and contextual meanings of Israeli wars in Lebanon. The experience gained from the Psychosocial Unit during the war helped influence these debates and spread more locally informed psychosocial forms of intervention that was thought to be more culturally and politically appropriate.

Psychosocial experiences during the July war were later transferred to the Naher al Bared conflict in 
2007, albeit in a more proficient and less experimental way. $\underline{45}$ These different conflicts have enabled the creation of different types of local mental health resources on how to respond to psychological suffering. However, UN agencies like the UNHCR and international organizations still heavily rely on global and standardized indicators when it comes to assess the mental health of war-affected communities, like trauma and PTSD.46 This is especially visible in the Syrian refugee situation in Lebanon today, where most of these psychosocial local resources are not used by current humanitarian organizations. 47 In summary, this example highlights the ways in which local forms of expertise emerge and are formed and re-shaped out of direct contact with volunteer work during crises and wars. Doing psychosocial work during the war was practiced and performed by different volunteers and experts together. This eventually informed the design and structure of locally based mental health resources for war and conflict.

\section{Analysis and discussion}

The act of volunteering has implications on the level of future preparedness and responsiveness to war. The affective and inter-subjective transformation sensed on a personal level has the possibility and ability to shape and produce a kind of committed subjectivity, conscious of its role during war and conflict. As the first example showed, some of the volunteers during the July war became engaged local actors that can be mobilize and provide aid and support during war. This kind of preparedness to war is much more entrenched on the community level and much harder to teach, than one that needs to be taught as a professional procedure and concept. This is due to the fact that volunteering seems to form a kind of a political subjectivity by producing an affective and psychological form of consciousness of the social and political situation.

Moreover, volunteering produces a set of skills and local knowledge and expertise that are informed by the field and the demands of the war-affected communities. This type of local expertise, as shown in the next two examples on the Reconstruction Unit team and the Psychosocial team, are crucial in challenging and transforming global humanitarian programs of aid, like trauma and PTSD, as well as signal to and resist the political economy of post-war reconstruction, framed by the vision of donor societies, and hence leaving no room for local and communal participation on the level of rebuilding itself.

Crises like wars and conflicts bring with them a number of global humanitarian experts and expertise, alongside humanitarian programs to implement aid in a standardized and universalized manner. These experts function depending on specific international indicators and concepts like PTSD for example. As this case study showed, local experts, whose knowledge stems from volunteering during war, became a valuable resource as they transferred the field's "knowledge and needs" to change and shape global expertise and expectations in war. Local volunteering experts are actors that can determine and define the efficiency, success and rapidity of aid programs during emergency situations.

\section{Conclusion: implications for current humanitarian work}

Facing the forms of professionalized and standardized acts of relief and aid implemented by international humanitarian organizations at the end of the July war, many of the volunteers were recruited as NGO workers. The space for independent volunteering in crisis and war seems to have 
been transformed into a professionalized space, more attached to global policies, concepts and programs of aid than to the local and communal context and history. This case study showed that independent forms of volunteering and volunteering initiatives during war have the capacity and ability to produce active community workers who possess a set of skills and conscious commitment to support affected communities. Furthermore, it has shown that local forms of expertise, emergent from or informed by acts of volunteering, are crucial in steering and directing global forms of aid when they land in a specific site like Lebanon. These are very few investments in these forms of local expertise by international humanitarian organizations that, most times, bring their own global experts to direct and implement aid and support programs. More reliance on local forms of expertise and on local actors who have a political and social commitment to the community they are helping and supporting is needed to implement more efficient and appropriate interventions during war and in its aftermath.

\section{Bibliography}

Marie-Noëlle AbiYaghi, L'altermondialisme au Liban : un militantisme de passage. Logiques d'engagement et reconfiguration de l'espace militant (de gauche) au Liban, PhD thesis, 2013, Université Paris I Panthéon-Sorbonne.

Howayda Al-Harithy, Lessons in Postwar Reconstruction: case studies from Lebanon in the aftermath of the 2006 war, Routledge, 2010.

Sharika Thiranagama, In my mother's house: Civil war in Sri Lanka, University of Pennsylvania Press, 2013.

Fathia Saoudi, Oubli Rebelle: Beyrouth 82, L'harmattan, 1986.

Derek Summerfield, "A critique of seven assumptions behind psychological trauma programmes in waraffected areas", Social Science \& Medicine, Vol. 48, No. 10, 1999, pp. 1449-1462.

Lamia Moghnieh, "Local forms of relief during the July War in 2006 and international humanitarian interventions: implications on community preparedness for war and conflict", Civil Society Knwoledge Center, Lebanon Support, June 5th, 2015, available at: https://civilsociety-centre.org/paper/local-formsrelief-during-july-war-2006-and-international-humanitarian-interventions [last accessed on July 4th, 2015].

- 1. Samidoun has been the subject of an in-depth case study published by Lebanon Support. See Lamia Moghnieh, "Local forms of relief during the July War in 2006 and international humanitarian interventions: implications on community preparedness for war and conflict", Civil Society Knwoledge Center, Lebanon Support, June 5th, 2015, available at: https://civilsociety-ce ntre.org/paper/local-forms-relief-during-july-war-2006-and-international-humanitarianinterventions [last accessed on July 4th, 2015].

- 2. For recorded experiences of volunteering, refer to the Diary of Fathia Saoudi, a volunteer activist documenting her own experience along with other volunteers during the 1982 Israeli 
invasion of Lebanon; Fathia Saoudi, Oubli Rebelle: Beyrouth 82, L'Harmattan, 1986.

- $\underline{3}$. Both relief centers were located in Beirut and served as headquarters for aid distribution and relief work.

- 4. Emerging literature in anthropology have stepped away from studying war as a separate and detrimental event to studying it as a social phenomenon that creates transformations on the level of individuals and society. For example, see Sharika Thiranagama, In my mother's house: Civil war in Sri Lanka, University of Pennsylvania Press, 2013.

- 5. Lamia Moghnieh, op. cit. 1.

- $\underline{6}$. Interview with Bassem Chit, April 2013.

- 7. Interview with Tarek Abdallah, January 2015.

- 8. Interview with Mohamad Ali Nayel, March 2013.

- 9. Interview with Hiba Abbani, January 2015.

- 10. Interview with Tarek Abdallah, January 2015; Interview with Mohamad ali Nayel, March 2013.

- 11. Interview with Mohamad Ali Nayel, March 2013.

- 12. Interview with Hiba Abbani, January 2015; interview with Mohamad ali Nayel, April 2012.

- 13. Interview with Bassem Chit, March 2013.

- 14. Interview with Hiba Abbani, January 2015.

- 15. Interview with Hiba Abbani, January 2015; Interview with Mohamad ali Nayel, April 2012.

- 16. Not all volunteers remained to provide relief after the war. Many of them returned to their jobs and lives when the ceasefire went into effect. These two volunteers however were among those who continued volunteering after the war, which is both revelatory of the effect of volunteering on their convictions, but also an indication that their experience is not representative of all volunteers at Samidoun.

- 17. "Samidoun caused a big and radical change in my life and in my beliefs/values. I was in a transitional phase then (20 years old). I was raised in different place/background and did not know anything about these ajweiz2. So I was introduced to Samidoun and I was really impressed by the style of communication and work, I felt like I belonged to it". Interview with Hiba Abbani, January 2015.

- 18. On Lebanon: Marie-Noëlle AbiYaghi, 2013, "L'altermondialisme au Liban : un militantisme de passage. Logiques d'engagement et reconfiguration de l'espace militant (de gauche) au Liban", PhD thesis, Université Paris I Panthéon-Sorbonne.

- 19. "A lot of people had changes and transformations. How they made certain life decisions after volunteering at this collective. Because a lot of the people I met in Samidoun, when I see them now or after, they were people who had gone a major change. Their perception changed. Some people became more interested in becoming involved and active in certain topics. Others came back to their life normally. However, there were some who had a negative experience. " Interview with Hiba Abbani, January 2015.

- 20. Interview with Hiba Abbani, January 2015; interview with Mohamad Ali Nayel, April 2012.

- 21. Howayda Al-Harithy, Lessons in Postwar Reconstruction: case studies from Lebanon in the aftermath of the 2006 war, Routledge, 2010, p. viii.

- 22. On the founding of the Unit after the war, its mission and first tasks, Howayda Al-Harithy, op. cit. 21, pp. 12-14.

- 23. Interview with Abir Saksouk, April 2015.

- 24. Howayda Al-Harithy, op. cit. 21, p. xi. 
- 25. Ibid, p.13

- 26. Ibid.

- 27. Ibid.

- 28. Ibid.

- 29. Interview with Abir Saksouk, April 2015.

- 30. Ibid.

- 31. Ibid.

- 32. Ibid.

- 33. Ibid.

- 34. Ibid.

- 35. Ibid.

- 36. Howayda Al-Harithy, op. cit. 21.

- 37. Conversation with Najwa Sabra, April 2015.

- 38. Interview with Ola Ataya, October 2014.

- 39. Ibid.

- 40. Interview with Tarek Abdallah, January 2015.

- 41. Interview with Ola Ataya, October 2014.

- 42. Ibid.

- 43. Interview with Anissa Al Amine, October 2014.

- 44. Interview with Olay Ataya, October 2014.

- 45. Ibid.

- 46. For critiques of using PTSD in aid programs see Derek Summerfield, "A critique of seven assumptions behind psychological trauma programmes in war-affected areas", Social Science \& Medicine, Vol. 48, No.10, 1999, pp. 1449-1462.

- 47. Interview with Ola Ataya, April 2014. 